\title{
The Impact of Enterprise Resource Planning Systems on the Efficiency of Taiwanese Firms
}

\author{
Bi-Huei Tsai \\ Department of Management Science, National Chiao Tung University, Hsinchu City, Taiwan \\ E-mail address: joy@mail.nctu.edu.tw
}

\begin{abstract}
This paper seeks to ascertain how the turnover factors, vender features and industrial characteristics improve the firm efficiency under enterprise resources planning (ERP) systems. A comparison of DEA efficiency score is conducted between preERP and post-ERP phases based on 59 Taiwanese firms which implement ERP from 1998 to 2003. ERP adopters are found to reduce their turnover days of account receivables or inventories, and prolong turnover days of unpaid accounts permitted by their suppliers, thus causing a substantial efficiency elevation after ERP implementation. In addition, this article captures the greater efficiency advance based upon leading vendor packages. This suggests that the rapid efficiency growth under ERP formula is closely connected with the consulting supports of leading vendors. Furthermore, the electronics industry performs better than non-electronics industry after ERP installation, which implies "electronics firms' more reliance on such ERP mechanisms" to effectively integrate resources, and as a result enhance performance.
\end{abstract}

Keywords- Enterprise resource planning, ERP, Data envelopment, DEA, Efficiency.

\section{INTRODUCTION}

In today's highly competitive business environment, firms are becoming increasingly dependent on information technology (IT). The integration between various departments has also become ever more important. As a result, the operation of ERP systems has become a popular trend in the business industry for the recent years. Prior literature indicates that if a firm blindly invests in ERP systems without more extensive assessment, then there is a high possibility that the ERP implementation project may fail. In fact, $96.4 \%$ of firms experience ERP implementation failures [1]. Another research done by Al-Msshari [2] documented that $70 \%$ of firms implementing under ERP systems neither obtain nor reach its efficiency potential. When Kumar and Hillegersberg [3] evaluated the firms that implemented ERP systems in the past, the results were not satisfactory enough. It seems that firms face negative side effects. In addition to the failure risk of ERP installation, the implementation of ERP systems takes long time and requires substantial monetary investments [4,5]. A typical ERP installation has a total cost of about $\$ 15$ million [6] and the costs can be as high as $2 \%$ to $3 \%$ of revenues [7]. The installation requires from one to three years $(21$ months on average), with its benefits starting to accrue in an average of 31 months $[8,6]$. These evidence all indicates that ERP implementation is usually fraught with business risk [9].
Although numerous cases document the failure risk and heavy costs of ERP implementation, there remain an increasing number of firms which nevertheless decide to utilize the ERP system. The research paper done by Lu, Hsieh, Feng, and Hsu [10] examines and brings forth a possible model in which firms are able to improve foundry-service's quality and save customers' time and money. They describe how TSMC satisfies its subcontractors by integrating the assembly and final test data from subcontractors to provide consistent and correct data to customers. From Lu, Hsieh, Feng, and Hsu [10], the ERP system not only provides the linkage and integration of the various layers in the system but also decreases the costs and time of the procedure of data exchange. In addition to Lu, Hsieh, Feng, and Hsu's [10] arguments, prior researches proposed that firms relied more on information technology (IT) to boost their productivity as the world became more integrated in recent years $[11,12]$. It is worthwhile to investigate the critical factors of firms' efficiency elevation under ERP installation. Hence, this paper presents an approach to investigate the effect of ERP system (Enterprise Resource Planning) on technical efficiency through a two-stage analytical study with 470 firm-year observations. In the first stage, a nonparametric frontier method of data envelopment analysis (DEA) is employed to measure technical efficiency scores for the firm. In contrast to conventional DEA analysis, our study employs Banker and Morey [13] model to evaluate the firm's efficiency by considering the exogenous input variables and controllable factors separately, since firm-specific inputs (labors, capitals and raw materials) are discretionary under managerial control and the macroeconomic prosperity factors are not. The exogenous variable, gross domestic product (GDP) values are taken into account in measuring the firm's efficiency.

The second stage then utilizes the Tobit model to regress the efficiency scores upon account receivable turnover days, account payable turnover days and inventory turnover days. This study examines whether better sale or purchase order operations are attributed to efficiency improvements after ERP installation. The overall objective of this study is to complement the knowledge about the value of ERP investments at the firm level. This study specifically focuses on three dimensions of operational improvements, namely, credit sale management, purchase management, and inventory management, to examine what enhances enterprise perform better under ERP systems. The three financial criteria, turnover days of accounts receivable, inventory, and account 
payables, are employed as such three kinds of operational management proxies to examine how ERP system improves firm's productivity. This paper hopefully can explore the relations between the operational management and efficiency improvements under ERP system.

In addition to the turnover information disclosed in financial statements, this paper also highlights the nonfinancial determinants of efficiency elevation subsequent to ERP implementation. One of the non-financial factors is the characteristics of ERP vendor. This paper captures whether efficiency elevates to a greater extent for firms under ERP packages of leading vendors because of their rich consulting experiences to install ERP packages for the clients. The other non-financial factor is the industry factors. This paper compares the difference of efficiency improvement between electronics and non-electronics industry for Taiwanese industry for Taiwanese firms, because ERP implementation in Taiwanese electronics firms would be interesting and important. Besides its strong economy, Taiwan has achieved astonishing success in the electronics industry as one of the largest global suppliers of computer monitors and a leading PC manufacturer. Due to a great deal of electronics product exportations, Taiwanese electronics firms rely more on ERP platforms to integrate sale or purchase orders from global branches than non-electronics firms. It is more beneficial for electronics firms to install ERP systems. Through the comparison of efficiency improvement in electronics firms with that in non-electronics firms in this paper, we can realize the specific roles which ERP systems play in such exportoriented industry as Taiwan electronics firms.

Based on 59 Taiwanese firms which implement ERP systems, the empirical results show that ERP systems yield substantial efficiency boost to the firms that adopt them. There also appears to be superior levels of functional integration under ERP fittings. The turnover days of account receivable and inventory are reduced, while turnover days of account payable appear prolonged. In addition, the findings exhibit that the performance of ERP firms is negatively correlated to account receivable turnover days and inventory turnover days. Since the surplus and shortage of inventory in factories may be easily solved by ERP apparatus, the inventory turnover days can be curtailed after the ERP implementation, which leads to the superior firm's performance. Besides, firms implementing ERP systems can effectively integrate client orders from various branches and cut down account receivable turnover days, which results in efficiency advance. Furthermore, the performance of ERP firms is positively related to account payable turnover days. Since ERP systems enable suppliers to allow enterprises to prolong their payment days after ERP implementations. Enterprises can utilize more flexible cash flow after ERP installations and by doing so elevates the efficiency.

The contributions of this essay can be summarized as follows. First, the objective of this study is built on prior theory to compare efficiency differences between pre-ERP and postERP periods, which is utterly different from prior researches that evaluate the stock market reactions to ERP investment announcements to determine the added values of ERP systems.
In contrast to the market response, firm's efficiency is measured by the objective input and output factors in our study and is unlikely to be interfered by the market disclosed information, which is unrelated to the ERP systems. Second, this paper finds out critical factors of efficiency advance by means of ERP systems, so the findings invoke some interests in what firm's characteristics are suitable for ERP implementation. Since this paper exhibits the significant associations between firm efficiency and the turnovers of account receivables, inventories as well as account payables, manufactures who process a great deal of purchase or sale orders obtain more advantages than other enterprises. Finally, this paper inspires leading vendors in how to make decisions concerning ERP installment consulting in emerging markets. The greater effect of ERP implementation on efficiency improvements in Taiwan suggests that ERP vendors can take account of extending their service domain not only in developed areas but also in emerging markets, especially for such export-oriented manufactures as Taiwan electronics industry.

\section{HYPOTHESIS DEVELOPMENT}

\subsection{Assessment of ERP on firm performance}

Hitt, Wu and Zhou [14] revealed that firms implementing ERP systems showed significant improvements as apposed to those that did not invest in such systems. Firms implementing ERP systems show advantages of increased productivity rate, auto-manufacturing scheduling, unduplicated information, data sharing as well as a reduction in the costs of human resources required in a firm [15-16]. ERP systems are able to integrate all the different departments of production, sales, material, quality control, finance management, management accounting and information management together in order to allow for an efficient internal management and better customer service so as to meet with the rapidly evolving business. In order to investigate whether there are indeed substantial performance differences between companies that do and don't implement ERP systems, this paper sets the following hypothesis:

$$
\begin{gathered}
\mathrm{H}_{1}: \text { There are substantial differences in efficiency between } \\
\text { pre-ERP and post-ERP implementation. }
\end{gathered}
$$

\subsection{Determinants of efficiency improvement under ERP systems}

ERP system may customize accounts receivable module according to the business processes and effectively make collections of unpaid customer invoices from credit sales on a timely basis, so the accounts receivable levels can be easily reduced. All this avoids the bad debts from the customers and cuts down the account receivable collection days. After Arizona Electric Power Corporation implemented the J. D. Edwards ERP system, the days required to close sales dropped from 38 days to only 9 days, while the work order eased from 30 days to 2.5 days. From the above information, it can be seen that every aspect of the financial statement reveals that firms run better after implementing ERP systems. Thus, the following hypothesis can be erected: 
$\mathrm{H}_{2-1}$ : The reduction of account receivable turnover days improves the firm efficiency during the ERP implementation period.

In 1997, the American Production and Inventory Control Society (APICS) revealed an analytical report which showed firms with ERP systems have a $60 \%$ less inventory period when compared with its competitors. According to prior literature [17-20], ERP systems enhanced a balanced production and an increased cash flow, and thus elevated the firms' competitiveness in the market. Moreover, ERP systems not only increase the accuracy of inventory records but decrease inventory stock by $20 \%$. Firms are able to respond to market fluctuations in real time and adjust its inventory and thus lower inventory risks, increasing efficiency across the firm. With a view to investigating the effects of the inventory turnover days on the efficiency after implementing ERP systems, the following hypothesis is formed:

$\mathrm{H}_{2-2}$ : The reduction of inventory turnover days improves the firm efficiency during the ERP implementation period.

ERP systems provide a standard IT application platform for back-office functions that enable technical and business integration [21]. Gattiker and Goodhue [22] suggested that ERP systems were able to improve data visibility across a firm and allow the accuracy and integration of account payables, salary expenses, and tax payable, thus leading to more efficient enterprise-level transactions. A firm's management of account payables to its respective MDCs is central to the firm's efficiency. The longer the turnover days of account payables are, the greater the flexibility of fund maneuvering should be generated. Thus, the following hypothesis can be drawn:

$\mathrm{H}_{2-3}$ : Prolonged account payable turnover days improve the firm efficiency during the ERP implementation period.

Hayes et al. [23] also found greater market valuations for firms that announced investments in top vendors (SAP and PeopleSoft) over the period from 1990 to 1998. It could be argued that investing in an ERP package by a leading vendor would increase the likelihood of the best practices for crossfunctional business, thus increasing the potential for integration benefits. Especially, ERP implementations are known to be unusually difficult, so the success or failure hinges on the business knowledge of internal business experts and the technical skills of outside consultants [24]. The rich experiences of leading vendors are likely to decrease the probability of ERP implementation failures. This paper accordingly offered the following hypothesis:

\section{$\mathrm{H}_{3}$ : The efficiency will be greater for adoptions of ERP packages by leading vendors than by other vendors.}

In recent years Taiwan's high-tech electronics industry has occupied a great proportion of the nation's GDP. The fluctuation of gross income and pre-tax profit of Taiwan's electronic industry are considerably higher than other nonelectronics industries. Inasmuch as the life cycle of electronic industry is short, the profit variation and the risk of the business are also higher. Therefore, electronics industry requires more flexible cash flow management in order to decrease its risks. Since ERP systems enable the integration of the entire order flow which includes production, sales, human resources, research and development and finances, such systems are likely to facilitate the manufacturing management in the electronics industry. This paper compares the efficiency difference between electronics and non-electronics industry to investigate whether business efficiency is superior after the installation of ERP systems in the high-tech electronics industry. The following hypothesis is stated:

\section{$\mathrm{H}_{4}$ : There are substantial differences in efficiency between electronics and non-electronics industries.}

\section{RESEARCH DESIGN}

This study adopts a two-stage approach, Data Envelopment Analysis (DEA) and Tobit regression, to investigate the effect of ERP implementation on firms' efficiency. The first stage uses DEA methods to estimate the efficiency. In the second stage a Tobit regression model is employed to investigate efficiency factors.

\subsection{Efficiency measurement using DEA}

Charnes, Cooper and Rhodes [25] assumed constant returns to scale (CRS) in the basic DEA method to calculate technical efficiency (TE). In our study, the sample firms implement ERP in different year, so a pointed firm's efficiency is likely vary according to macroeconomic conditions. Banker and Morey [13] emphasized that it was reliable to evaluate the firm's efficiency by considering the exogenous input variables and controllable factors separately, since firm-specific inputs (labors, capitals and raw materials) are discretionary under managerial control while the macroeconomic prosperity factors are not. As a result, this paper applies Banker and Morey's [13] DEA model and is additionally based upon the exogenous variable, gross domestic product (GDP) values to capture this uncontrollable macroeconomic prosperity factors. The inputs are partitioned into two parts, controllable inputs (labors, capitals and raw materials) and exogenous inputs (GDP). The DEA model in our study can be formulated as a fractional linear programming problem as equation (1).

$$
\begin{aligned}
& T E_{j}=\operatorname{Min} \theta-\varepsilon\left({s_{c}}^{+}+s_{F}{ }^{+}+s^{-}\right), \\
& \text {s.t. } \sum_{j=1}^{n} \lambda_{j} X_{i, C j}+s_{C}{ }^{+}=\theta X_{C A}, \quad i=1,2,3, \\
& \quad \sum_{j=1}^{n} \lambda_{j} X_{F j}+s_{F}{ }^{+}=\theta X_{F A}, \\
& \sum_{j=1}^{n} \lambda_{j} Y_{j}-s^{-}=Y_{A}, \\
& \quad \lambda_{j}, s_{c}{ }^{+}, s_{F}{ }^{+}, s^{-} \geq 0, \quad j=1, \ldots, n,
\end{aligned}
$$

where $T E_{j}$ is technical efficiency; $\theta$ represents the maximum proportion of input levels that can be employed to procure current output levels for the $j$ th DMU; 
$Y_{j}$ is the output for the $j$ th DMU and $X_{i, c j}$ is the $i$ th controllable input (labors, capitals and raw materials) for the $j$ th DMU; The number of employees, fixed assets, and raw materials are employed as labor, capital and raw material factors. Net sale revenues are introduced as the measure of the output. $X_{F j}$ is the $j$ th exogenous input (GDP) for the $j$ th DMU; $\lambda_{j}$ is the weight of the $j$ th DMU; and $S^{+}{ }_{c},, S^{+}$, and $S^{-}$ are the controllable input surplus, the exogenous input surplus, and the output slacks, respectively.

Given the CRS assumption, this can also be represented by a unit isoquant in input/input space. However, the CRS assumption is only appropriate when all (DMUs) are operating at an optimal scale. Imperfect competition, constraints on finance, etc., may cause a DMU to be unable to operate at optimal scale. Banker, Charnes and Cooper [26] suggested an extension of the CRS DEA model to account for variable returns to scale (VRS) situation. The use of the CRS specification, when not all DMUs are operating at the optimal scale, will result in measures of TE which are confounded by scale efficiencies (SE). The use of the VRS specification will permit the calculation of TE devoid of these SE effects. The CRS linear programming problem can be easily modified to account for VRS by adding the convexity constraint N1' $\lambda=1$ in equation (2) to provide:

$$
\begin{aligned}
& P T E_{j}=\operatorname{Min} \theta-\varepsilon\left(s_{c}{ }^{+}+s_{F}{ }^{+}+s^{-}\right), \\
& \text {s.t. } \sum_{j=1}^{n} \lambda_{j} X_{i, C_{j}}+s_{C}{ }^{+}=\theta X_{C A} \text {, } \\
& \sum_{j=1}^{n} \lambda_{j} X_{F j}+s_{F}^{+}=\theta X_{F A}, \\
& \sum_{j=1}^{n} \lambda_{j} Y_{j}-s^{-}=Y_{A}, \\
& \sum_{j=1}^{n} \lambda_{j}=1 \text {, } \\
& \lambda_{j}, s_{c}{ }^{+}, s_{F}{ }^{+}, s^{-} \geq 0, j=1, \ldots, n,
\end{aligned}
$$

where $P T E_{j}$ is pure technical efficiency. The CRS technical efficiency (TE) measure is decomposed into "pure" technical efficiency (PTE) and scale efficiency (SE) as the following equation.

$$
T E_{j}=P T E_{j} * S E_{j} .
$$

This study conducts Mann-Whitney $U$ test to verify whether the firm's TE, PTE, and SE, modeled with and without ERP system, has significantly different result. The MannWhitney $U$ test is one of the nonparametric statistical methods used to test the efficiency scores of a pair of differing observations. We use statistical methods to see whether there are indeed significant differences in TE, PTE, and SE after ERP implementation for the sample firms to test hypothesis $\mathrm{H}_{1}$.

\subsection{Efficiency determinants using Tobit regressions}

To identity factors impacting the efficiency improvement under ERP systems, this article applies Tobit regressions to regress TE, PTE and SE on not only financial turnover factors but non-financial features as follows:

$$
\text { Efficiency }=f(A R D, I T D, A P D, \text { Vendor, ELE }),
$$

where technical efficiency (TE), scale efficiency (SE), and pure technical efficiency (PTE) are chosen as the efficiency indicators. ARD, ITD, and APD represent account receivable turnover days, inventory turnover days and account payable turnover days. Vendor is a dummy variable. If the sample firms operating under SAP and Oracle, the variable $E L E$ is equal to 1; otherwise, the $E L E$ is equal to 0 . Besides, the $E L E$ is another dummy variable. If the sample firms belong to the electronics industry, the variable $E L E$ is equal to 1 ; otherwise, the $E L E$ is equal to 0 .

\section{DATA AND SAMPLES}

This research focuses on the Taiwanese listed firms which implement ERP systems ranging from 1998 to 2003. We further make use of following sources, Financial Supervisory Commission, Taiwan Stock Exchange Market Observation Post System, Central News Agency Clippings System, Taiwan Economic Journal (TEJ) database as well as the Google searches under the keywords "ERP" or "enterprise resource planning" to capture the lists of firms which implement ERP system. A total of 59 firms were drawn from the aforementioned sources as our study sample firms. In addition, the ERP implementation years of the 59 sample firms are set year 0 in our study. Negative years represent years prior to the ERP implementation year and positive years represent years subsequent to the ERP implementation year. These sample firms implement ERP system in different year ranging from 1998 to 2003, but the inputs factors, output factors and financial turnover day data of such firms are collected from 1996 to 2005 in this article. As a result, some firms which implement ERP systems after 2000 do not contain the complete data ranging from year 3 to year 6 . Totally 470 firm-year observations are collected in our article. The data of input factor, output factors and financial ratios are collected from Taiwan Economic Journal (TEJ) Database.

\section{EMPIRICAL RESULTS}

5.1 The efficiency comparison between pre-ERP and postERP implementation period

The results of efficiency reveal the substantial amounts of progress in the SE after ERP implementation. On the contrary, the PTE remains declining after ERP installation, and the PTE does not increase until the five year subsequent to ERP implementation. To prove that efficiency difference between the pre-ERP and post-ERP implementation, this paper uses the Mann-Whitney $U$ test to verify the findings. Table 1 exhibits the results of Mann-Whitney U test. It is found that the TE or SE is significantly higher and better after firms use ERP systems. Consistent with the hypothesis $\mathrm{H}_{1}$, the $\mathrm{Z}$ statistics under $U$ test also confirm the TE or SE prior to ERP implementation is significantly different from that subsequent to ERP system at $1 \%$ significant level. Especially, once we 
separate the non-electronics industry from the electronics industry and look at them individually, we find that the electronics firm implementing ERP system show enhanced efficiency. In electronics industry, the $Z$ statistics under $U$ test show the significant difference in TE or SE between pre-ERP and post-ERP period at $1 \%$ significant level. It is evident that ERP systems benefit a firm's operation efficiency.

Table 1 Efficiency difference between pre-ERP and postERP implementation

\begin{tabular}{cc|c|c}
\hline \hline & $\begin{array}{c}\text { Technical } \\
\text { Efficiency }\end{array}$ & $\begin{array}{c}\text { Pure Technical } \\
\text { Efficiency }\end{array}$ & $\begin{array}{c}\text { Scale } \\
\text { Efficiency }\end{array}$ \\
\hline Full sample & 0.0976 & -0.0325 & 0.2563 \\
Z-statistics & $4.6102^{* * *}$ & $-2.3035^{* *}$ & $8.5528^{* * *}$ \\
\hline Electronics & 0.1954 & 0.0350 & 0.3246 \\
Z-statistics & $5.1649^{* * *}$ & 0.2215 & $7.4371^{* * *}$ \\
\hline Non-Electronics & 0.0159 & -0.0859 & 0.1982 \\
Z-statistics & $2.4788^{* * *}$ & $-2.9847^{* * *}$ & $4.9109^{* * *}$ \\
\hline \hline
\end{tabular}

Note: ${ }^{*}$ Significant at the $10 \%$ level. ${ }^{* *}$ Significant at the $5 \%$ level. ${ }^{* * *}$ Significant at the $1 \%$ level.

The majority of the listed firms in Taiwan are of the manufacturing industry, and with the world becoming a global village, firms are looking to elevate their SE in order to minimize costs so as to enhance competitiveness. It is observed that with the help of information technology, firms are now able to make the best of their resource allocation. ERP systems do exactly integrate the various divisions in a factory. The expansion of the production scale not only reduces costs, but also allows the firm to become more competitive as a result of the cost advantage. It is able to link the finished goods to the raw materials inventory, and in so doing it allows the SE to upgrade. Furthermore, the TE boost is mainly driven by the SE improvement. On the other hand, PTE do not show any obvious signs of improvements as far as ERP systems go. In fact, firms from the non-electronics industry are found to have lowered PTE. It is possibly caused by the time lag for the organizations to adapt to such new systems as the arguments.

\subsection{Results of Tobit regression analysis}

This section explores the determinants of a firm's efficiency improvement surrounding the ERP implementation periods, ranging from year -2 (two year prior to ERP implementation) to year 6 (six year subsequent to ERP implementation). Table 2 depicts the results of the Tobit regression analyses, with TE, PTE and SE as dependent variables, respectively. The coefficients of account receivable turnover days are negative. The results of t-statistics show that $\mathrm{TE}$ and SE seem to be significantly and negatively related to account receivable turnover days at $1 \%$ level, which suggests that during the ERP implementation years, the fewer days a firm spends on receiving their account from the credit sales, the higher the efficiency will be seen. With the assistance of ERP systems, firms can integrate information from branch offices distributed over the globe to form one unified set of data, and in so doing shorten the credit sale process. As a result, account receivable turnover days decrease after ERP installation, as shown in Table 2. Consequently, the efficiency performs better after ERP implementation. Consistent with hypothesis $\mathrm{H}_{2-1}$, the efficiency improvements from ERP system are driven by the curtailment of account receivable days.

Table 2 Results of efficiency regressed on financial and non-financial factors

\begin{tabular}{|c|c|c|c|c|c|c|}
\hline & \multicolumn{2}{|c|}{$\underline{\mathrm{TE}}$} & \multicolumn{2}{|c|}{$\underline{\text { PTE }}$} & \multicolumn{2}{|c|}{$\underline{\mathrm{SE}}$} \\
\hline & Coefficient & T-statistics & Coefficient & T-statistics & Coefficient & T-statistics \\
\hline \multicolumn{7}{|l|}{ Financial factor } \\
\hline $\begin{array}{c}\text { Accounts } \\
\text { receivable } \\
\text { turnover days }\end{array}$ & -0.1035 & $-3.5820^{* * *}$ & -0.0778 & $-1.9782^{* *}$ & -0.2729 & $-6.1416^{* * *}$ \\
\hline $\begin{array}{c}\text { Inventory } \\
\text { turnover days }\end{array}$ & -0.1180 & $-5.0435^{* * *}$ & -0.0992 & $-3.1237^{* * *}$ & -0.2093 & $-5.8219^{* * *}$ \\
\hline $\begin{array}{c}\text { Accounts } \\
\text { payable } \\
\text { turnover days }\end{array}$ & 0.0927 & $2.4085^{* *}$ & 0.0760 & 1.4517 & 0.0352 & 0.5950 \\
\hline \multicolumn{7}{|c|}{ Non-financial factor } \\
\hline $\begin{array}{l}\text { Leading } \\
\text { Vendor }\end{array}$ & 4.2517 & $2.3735^{* *}$ & -9.4302 & $-3.8754^{* * *}$ & 22.9976 & $8.3363^{* * *}$ \\
\hline $\begin{array}{l}\text { Electronics } \\
\text { Industry }\end{array}$ & 13.1288 & $6.9755^{* * * *}$ & 21.9419 & $8.5840^{* * *}$ & -0.1226 & -0.0424 \\
\hline Constant & 16.7761 & $6.4078^{* * * *}$ & 28.6319 & $8.0536^{* * *}$ & 78.4444 & $19.5276^{* * *}$ \\
\hline $\mathrm{R}^{2}$ & 0.2802 & & 0.2414 & & 0.3420 & \\
\hline Adjusted $\mathrm{R}^{2}$ & 0.2708 & & 0.2315 & & 0.3335 & \\
\hline
\end{tabular}

The coefficients of inventory turnover days shown in Table 2 are all negative. The results of t-statistics unveil that efficiency indicators appear to be significantly and negatively related to inventory turnover days at $1 \%$ level. This suggests that during the ERP implementation years, the fewer days a firm spends on selling their finished goods inventory after the production process, the higher the efficiency appears. We may conclude that ERP systems enable the integration of data within several factories and allow raw materials or factory labors inputs working at optimal levels via the standard inventory management. Firms operating under ERP systems make effective use of their resources and as a result cause a significant decline in their average inventory turnover days. Hence, the inventory turnover improvement contributes to the efficiency boost after ERP implementation. Consistent with hypothesis $\mathrm{H}_{2-2}$, the efficiency improvements from ERP system are attributed to the cut-down of inventory process.

In addition, Table 2 exhibits that $\mathrm{TE}$ is positively associated with the turnover days of account payable. The greater the days of account payable are, the greater the efficiency is. Since ERP systems enable both the economies of scale and the effective management of firms, such firms are able to bring about their suppliers' permissions to prolong the period of unpaid account after ERP implementation. The efficiency improves due to the flexible cash flow once firms delay to pay for their purchase. In regards to non-financial characteristics, the coefficient of leading vendor variable is positive for TE and SE. Firms with SAP or Oracle systems have significantly better efficiency than the other firms after 
ERP implementation. Therefore, we may safely infer that the cause of such rapid growth in efficiency is a conjoined result of the support from experienced consultant agents. The findings are consistent with hypothesis $\mathrm{H}_{3}$. In addition, the coefficients of electronics industry dummies are significantly positive in Tobit regressions as the dependent variables are TE and PTE. The electronics industry performs superior to nonelectronics industry after ERP installation. Consistent with $\mathrm{H}_{4}$, electronics firms have more advantages than non-electronics in ERP development because employees and staff in the electronics industry get accustomed to such information technology more smoothly than those in other industries.

\section{CONCLUSIONS}

Empirical data results have provided general support for our hypotheses. We find that ERP adopters are consistently higher in performance across a wide variety of efficiency measures after ERP implementations. Overall, this suggests that indeed ERP systems yield substantial benefits to the firms that adopt them. There also appears to be superior levels of functional integration under ERP fittings. The turnover days of account receivable are reduced from 68 days (two years prior to ERP installation) to 52 days (six years subsequent to ERP installation). The turnover days of inventory decline from 70 days (two years prior to ERP installation) to 48 days (six years subsequent to ERP installation). On the other hand, ERP implementation firms prolong the turnover days of account payable from 45 days (ERP installation year) to 50 days (five years subsequent to ERP installation).

Furthermore, this article finds that a firm's efficiency is closely related to the turnover days of account receivable, inventory and account payable. This suggests the efficiency elevation is driven by the functional integration under ERP fittings. More interestingly, this article captures the greater efficiency advance under leading vendor packages (SAP and Oracle) than under other vendor packages. The efficiency boost is also found to be greater for electronics than non-electronics firms. This all demonstrates the non-financial impact, industry and vendor characteristics, on the firm efficiency after ERP implementation. Since ERP systems enable the integration of the entire functions which include production, sales, human resources, research and development along with finances, such systems facilitate effective management in the electronics industry.

In spite of the critical findings mentioned above, this paper only traces to the firm's performance for the six years subsequent to ERP installation. While our data does not currently allow more detailed analysis of the long-term impact on productivity (due to lack of long-term post-implementation data at this time), both of these issues, I believe, are promising areas for future research.

\section{REFERENCES}

[1] Rao, S.S. 'Enterprise resource planning: business needs and technologies', Industrial Management and Data Systems, Vol. 100, No. 2, pp.81-88, 2000.

[2] Al-Mashari, M. 'Construct of process change management in an ERP context: a focus on SAP R/3', Proceedings of the $6^{\text {th }}$ Americas Conference on Information Systems (AMCIS), Long Beach, CA, USA, pp. $980-997,2000$
[3] Kumar, K. and Hillegersberg, J.V. 'ERP experiences and evolution', Communications of the ACM, Vol. 43, No. 4, pp.22-26,April 2000.

[4] Bailey, J. 'Trash haulers are taking fancy software to the dump', Wall Street Journal, June 1999.

[5] White, J., Clark, D. and Ascarelli, S. 'This German software is complex, expensive and wildly popular', Wall Street Journal, March 17, pp.1, 1997.

[6] O’Leary, D.E. Enterprise Resource Planning Systems: Systems, Life Cycle, Electronic Commerce, and Risk, Cambridge University Press, 2000.

[7] Escalle, C., Cotteleer, M. and Austin, R. 'Enterprise resource planning (ERP)', Harvard Business School Case, No. 9, pp699-1020, 1999.

[8] McAfee, A. 'The impact of enterprise resource planning systems on company performance', Paper presented at Wharton Electronic Supply Chain Conference, Philadelphia, 1999.

[9] Austin, R.D. and Cotteleer, M.J. 'Current issues in IT: enterprise resource planning and ecommerce', Harvard Business School Press, Boston, MA, October 1999.

[10] Lu, J.J., Hsieh, D.S.T., Feng, E.C.C. and Hsu, I.H.W. 'B2B in TSMC turnkey services', Proceedings of IEEE International Symposium of Semiconductor Manufacturing, pp.41-44, 2001.

[11] Mukhopadhyay, T., Lerch, F. and Mangal, V. 'Assessing the impact of information technology on labor productivity: a field study', Decision Support Systems, Vol. 19, No. 2, pp.109-122, Feb 1997.

[12] Mukhopadhyay, T., Rajiv, S. and Srinivasan, K. 'Information technology impact on process output and quality', Management Science, Vol. 43, No. 12, pp.1645-1659, Dec 1997.

[13] Banker, R.D. and Morey, R.C. 'Efficiency analysis for exogenously fixed inputs and output', Operations Research, Vol. 34, No. 4, pp.513521,Sep 1986.

[14] Hitt L.M., Wu, D.J. and Zhou, X. 'Investment in enterprise. resource planning: business impact and productivity measures', Journal of Management Information Systems, Armonk, Summer 2002.

[15] Cotteleer, M.J. and Bendoly, E. 'Order lead-time improvement following enterprise-IT implementation: an empirical study', MIS Quarterly, Vol. 20, pp. 643-667, Sep 2006.

[16] Elaine, L.A. 'How to survive ERP', Datamation , pp.50-53, March 1997.

[17] Michael, H. 'ERP's silent benefits', Manufacturing Systems, Vol. 16, Iss. 11, pp.120, Nov. 1998.

[18] Seifert, M. 'Computer products company increases competitiveness with ERP software', Manufacturing Systems, pp.6-9, Nov 1993

[19] Barua, A., Kriebel, C.H. and Mukhopadhyay, T. 'Information technologies and business value: an analytical and empirical investigation', Information Systems Research, Vol. 6, No. 1, pp.3-23, Mar 1995.

[20] Stratman, J.K. and Roth, A.V. 'Enterprise resource planning (ERP) competence constructs: two-stage multi-item scale development and validation', Decision Sciences Journal, Vol. 33, No. 4, pp.601-628, fall 2002.

[21] Weill, P. and Vitale, M. 'What IT infrastructure capabilities are needed to implement e-business models', MIS Quart Executive, Vol. 1, No. 1, pp.17-34, March 2002.

[22] Gattiker, T.F. and Goodhue, D.L. 'Understanding the plant level cost and benefits of ERP: will the ugly duckling always turn into a swan', Proceedings of the 33rd annual Hawaii international conference on system sciences, IEEE Computer Society Press, Los Alamitos, CA, January 2000.

[23] Hayes, D.C., Hunton, J.E. and Reck, J.L. 'Market reaction to ERP implementation announcements', Journal of Information Systems, Vol. 15, No. 1, pp.3-18, 2001.

[24] Osterle, H., Feisch, E. and Alt, R. 'Business networking: relationships on the Internet', New York: Springer, 2000.

[25] Charnes A., Cooper W.W. and Rhodes E. 'Measuring the efficiency of decision making units', European Journal of Operational Research, Vol. 2, No. 6, pp.429-444, Nov 1978.

[26] Banker, R.D., Charnes, A. and Cooper, W.W. 'Some models for estimating technical and scale inefficiencies in data envelopment analysis', Management Science, Vol. 30, No. 9, pp.1078-1092., Sept. 1984. 